\title{
A brief history of wood use and forest management in Alaska $^{1}$
}

\author{
by Tricia L. Wurtz ${ }^{2}$ and Anthony F. Gasbarro ${ }^{3}$
}

\begin{abstract}
The Native peoples of Alaska used wood for fuel, for the construction of shelters, and for a variety of implements. Explorers, fur traders, gold miners, and settlers also relied on Alaska's forest resource. The early 20 th century saw the creation of the Tongass and Chugach National Forests in coastal Alaska, where large-scale harvesting began shortly after World War II. By 1955, two 50year contracts had been signed, committing 13 billion board feet of sawlogs and pulpwood. The commercial forest land base in Alaska has been dramatically reduced by a variety of legislative acts, including the Statehood Act of 1959 and the Alaska National Interest Lands Conservation Act of 1980.
\end{abstract}

Key words: forest history, Alaska, aboriginal use of forests, fuelwood, sternwheeled riverboats, gold mining, land classification, National Forests, Alaska Native Claims Settlement Act, Alaska National Interest Lands Conservation Act
Les peuples amérindiens de l'Alaska ont utilisé de bois à des fins de chauffage, de construction d'abri, ainsi que pour de multiples usages. Les explorateurs, les commerçants de fourrure, les chercheurs d'or, et les colons ont aussi compté sur la ressources forestière de l'Alaska. Le début du $20^{\mathrm{e}}$ siècle a vu la création des forêts nationales de Tongass et de Chugach sur le littoral de l'Alaska, site des premières opérations d'exploitation à grande échelle après la Deuxième guerre mondiale. En 1955, deux contrats de 50 ans avaient été signés, allouant 13 milliards de pieds mesure de planche sous forme de billes de sciage et de pâte. La superficie de forêts commerciales en Alaska a été réduite de façon dramatique du fait de plusieurs lois, dont le "Statehood Act" de 1959 et l' "Alaska National Interest Lands Conservation Act" de 1980.

\section{Wood Use by Native Peoples}

Before contact with Europeans, the Athabaskan people of interior Alaska depended on trees to a greater extent than any other culture in history (McGhee 1989). Wood was their sole fuel for heating, a requirement for survival in this climate. Before iron tools found their way from European whalers to Eskimos to Athabaskans in the interior, native people used sharpened stone tools to cut wood. They used the "beaver method," chipping around and around the tree until it could be felled (Nelson 1986). Athabaskans used trees in numerous ways. The wood of white spruce was used to construct shelters, for building canoes and rafts, fish traps, dog sleds, and later, fish wheels. The bark was used as roofing material, the boughs for shelter and insulation, the roots were used for lashing baskets, fishnets and snares. The wood from birch trees was specially prized for making snowshoes, and the bark was used for baskets and canoes.

The Tlingit and Haida peoples of coastal Alaska used their large trees in a distinctive architecture: houses consisted of huge planks set into a framework of heavy posts. They carved totem poles and canoes from red and yellow cedar. Red alder was used for dishes; the wood from yew trees was used for hunting bows and canoe paddles (Billman 1975).

\footnotetext{
${ }^{1}$ A paper presented at the Ecology and Silviculture Working Group session at the SAF National Convention held at Anchorage, Alaska, on 18-22 September 1994. It is also being published in the proceedings of that conference.

${ }^{2}$ USDA Forest Service, Institute of Northern Forestry, 308 Tanana Drive, Fairbanks, Alaska 99775-5500.

${ }^{3}$ Alaska Cooperative Extension, University of Alaska Fairbanks, Fairbanks, Alaska 99775.
}

\section{Early Exploration and Settlement by Europeans}

The coastal people were the first Native Alaskans to come into contact with Europeans, when Russian explorers first came ashore in 1741. During their occupation of Alaska from 1741 to 1867 , the Russians made considerable use of the forests around their settlements. Some historians believe that the first sawmill in Alaska was built at Redoubt Bay in 1833 (Harris et al. 1974). The Russians exported Alaskan logs and lumber to Macao, Canton, Chile, and California (Rakestraw 1981; Harris et al. 1974). The first attempt at afforestation for wood production in North America was made by the Russians around 1805 . Sitka spruce seedlings were planted on naturally treeless Unalaska Island in the Aleutian Islands (Bruce 1993). It is not known how many trees were originally planted, but in 1963 (158 years later), six trees were still alive and averaged 26 feet in height and 23 inches in diameter.

As the Russians were exploiting the resources of coastal Alaska, fur traders moved into western Canada and the upper Yukon River region in Alaska. In 1847, the Hudson Bay Company established a fur trading post and fort at Fort Yukon, Alaska (Newman 1989). This settlement was constructed with spruce logs, with spruce bark used as roofing material. Sternwheeled riverboats first operated on the Yukon in 1869; this marked the beginning of the relatively large-scale use of the river's riparian fuelwood resources. In 1887, Dawson City reported three small sternwheelers on the lower Yukon supplying the miners and local Alaskan Natives with supplies (Trimmer 1898).

\section{The Gold Rush (1886-1910)}

In Alaska, gold was first discovered in the 40-Mile River area in 1886 (Naske and Slotnick 1987). This find was over- 
shadowed by the discovery of gold in the Klondike ten years later. The Klondike gold rush was one of the largest in history, and the shortest route to the Klondike was through Alaska. The forest resources of this area were used to provide heat and shelter for the settlers and to meet the needs of miners. Miners required lumber for house construction, and for flumes and sluice boxes. In 1898, Dawson City was reported to have 12 sawmills producing a total of 12 million board feet annually.

As mining activity increased, sternwheelers became increasingly common. The river steamer system required large amounts of fuelwood. Woodcutters contracted with riverboat owners to supply stacked cordwood at rivers' edge. They were paid about $\$ 4$ per cord. All in all, over a thousand different steamers operated in the Yukon drainage. To make the 913 mile round-trip between Dawson City and the Upper Yukon, a steamer required between 100 and 150 cords of wood.

By the early 1930s, most of the accessible timber along the Yukon was exhausted and lumber demand was met by imports from British Columbia. When the Alaska Railroad was completed, the demand for riverboat service declined. The last sternwheeler operated in Alaska in 1956.

\section{Establishment and Early Years of the National Forests}

While the early use of the forests in the interior was tied mostly to the gold rush, in coastal Alaska, the primary use of forests by white men before the turn of the century was to support the fishing industry. The first salmon cannery in southeast Alaska was built in 1878 , and by 1889 there were 37 canneries as well as 11 sawmills (Rakestraw 1981). Hemlock was used for lumber and Sitka spruce for salmon packing cases, barrels and buildings.

During this time, people went onto public domain lands and cut timber wherever they wanted. Once a year a General Land Office agent would visit a mill and ask how much had been cut. The mill then settled up on the basis of "innocent trespass," at 20 cents per thousand board feet for sawtimber. In 1902, however, President Theodore Roosevelt established, by presidential proclamation, the Alexander Archipelago Forest Reserve (Rakestraw 1981). The reserve charged 50 cents per thousand for sawtimber (Rakestraw 1981). The Tongass National Forest was established in 1907, and a year later, the Alexander Archipelago Reserve and the Tongass were combined into a single National Forest, the Tongass, with 6.7 million acres (Rakestraw 1981). The Chugach National Forest was established in July 1907, including almost 5 million acres. By 1909 it had been enlarged to 11 million acres.

A long period of slow development followed the establishment of the national forests. In 1915, there were 75 salmon canneries in the Tongass and the Chugach. Fox farming was common, and the Forest Service rented out islands for $\$ 25$ per year. In 1915 , only 15 percent of the lumber used in Alaska was produced locally. Timber sales increased, so that by 1925 only 15 percent had to be imported (Rakestraw 1981).

During WWII, the Alaska Spruce Log Program provided Sitka spruce for the production of mosquito bomber airplanes. Huge rafts of spruce logs were towed by tug boats to Puget Sound for milling. In a year and a half, 38.5 million feet of high-grade spruce was towed south (Rakestraw 1981).

\section{Interior Alaska (1910-Present)}

By 1910, Fairbanks had 3000 people, and together with the surrounding gold mining operations utilized about 60,000 cords of wood annually. The forest surrounding Fairbanks also supported three sawmills, two of which produced $20 \mathrm{mbf}$ each day. Lumber production throughout the Interior amounted to $6 \mathrm{mmbf}$ annually (Kellogg 1910).

As more and more people settled in Interior Alaska, concern arose about the negative impact of wildfire on the area's timber and game resources. Between 1898 and 1939, an estimated one million acres burned annually. The General Land Office began fire patrols along the Alaska Railroad in 1921. The Alaska Fire Control Service was established in 1939. By the late 1950s, the Bureau of Land Management (BLM) was providing blanket fire-fighting coverage of interior Alaska. Now the State of Alaska and BLM share fire-fighting responsibilities (Pyne 1982).

During and shortly after WWII, the Department of the Interior reported that there were 69 sawmills operating in Interior Alaska and that somewhere between 25 and $50 \mathrm{mmbf}$ were sold annually (USDI 1951). Some of this timber was utilized in the construction of the Alaska Highway. In 1964 it was reported that there were 30 sawmills operating and that these produced approximately $6 \mathrm{mmbf}$ (University of Alaska 1964).

The Alaska Statehood Act of 1959 and the Alaska Native Claims Settlement Act of 1971 removed most of Interior Alaska's commercial forest land base from the public domain. Most of this commercial forest land of 10 million acres available for harvesting is now about evenly divided between the State of Alaska and Alaska Native Corporations (USDA Forest Service 1993a).

Beginning in the early 1970 s, the amount of timber being harvested from Interior Alaska forests began to increase slowly. A small export market developed for cants which were shipped to tidewater via the Alaska Railroad. The potential uses of Interior Alaska's timber resources on state lands were recognized in 1978 with the passage of the Forest Resources Practices Act, which established the Division of Forest Land \& Water Management, the predecessor of the Alaska Division of Forestry. In the early 1980 s, two state forests were established, the Haines State Forest Resource Management Area, and the Tanana Valley State Forest. Also during this time, some of the Alaska Native Corporations in the interior began to inventory their forest resources and conduct small timber sales for export.

In 1984, the Alaska Primary Manufacturing Law was struck down by the U.S. Supreme Court. The Court ruled that the State of Alaska did not have the authority to require that timber harvested on state land be processed before being exported from the state. Since that time a large proportion of logs from state timber sales have been exported. Round logs are also being shipped from Native corporation lands to the Pacific Rim countries and to mills in the Pacific Northwest. Logs not exported supply local sawmills which continue to produce small amounts of green air-dried lumber.

Most recently there have been attempts at developing larger-scale forestry in Interior Alaska. Several firms have shown interest in either establishing manufacturing plants or in producing chips for the export market. These operations have not materialized mostly because of economic conditions, and partly because of concerns about long-term sustainable 
supplies of wood fiber due to the uncertainty of landowner goals.

The total annual harvest from all of Interior Alaska probably does not exceed 30 million board feet, which is about five percent of the total harvest from all of Alaska forest lands. The most active harvesting, which is mostly for export, is now occurring on the Kenai Peninsula where Alaska Native corporation lands are being harvested. The State of Alaska is also planning timber sales in the area to salvage beetle-killed spruce timber.

\section{Coastal Alaska (WWII-Present)}

For many years there had been great interest in the the idea of pulp production on the Tongass National Forest. There were several unsuccessful attempts to develop pulp production facilities, but by 1955 , two 50 -year contracts had been signed committing approximately 13.5 billion board feet of sawlogs and pulpwood (Arthur D. Little Inc. 1961). Both Ketchikan and Sitka had a dissolving pulp mill by 1960 . These two pulp mills, along with three large sawmills, accounted for most of the harvest of $395 \mathrm{mmbf}$ in 1963, up from $55 \mathrm{mmbf}$ in 1950 (University of Alaska 1964). Harvest volumes from the Chugach National Forest remained relatively small at 2-8 mmbf annually (University of Alaska 1964).

As happened in Interior Alaska, the Alaska Statehood Act and the Alaska Native Claims Settlement Act changed ownership patterns in coastal Alaska. Four hundred thousand acres of the Tongass and Chugach National Forests were selected by the State of Alaska under the Statehood Act (USDA Forest Service 1994). This resulted in 160,000 acres being removed from the commercial forest land base of the Tongass National Forest. Another 460,000 acres of the commercial forest land base of the Tongass and a large portion of the commercial forest land base of the Chugach National Forest was selected as a result of the Alaska Native Claims Settlement Act (USDA Forest Service 1994).

Reductions of the commercial forest land base have continued. As a result of the Alaska National Interest Lands Conservation Act of 1980, 1.6 million acres of commercial forest lands in the Tongass National Forest were classified as National Monuments and Wilderness Areas. This Act had an impact on the classification of lands throughout the state. Statewide, 104 million acres of the public domain were placed into the various conservation systems (Gallagher and Gasbarro 1989).

Land classification for the protection of wildlife, recreation and scenic values has continued in southeast Alaska and has resulted in further declines in the commercial forest land base. The revised Tongass Land Management Plan of 1979 and the Tongass Timber Reform Act of 1990 have further reduced the commercial forest land base of the Tongass. As a result of these land reclassifications, the original 6.4 million acres of commercial forest land has now been reduced to 1.7 million acres (USDA Forest Service 1994). These constraints to timber supply will affect the nature of the forest products industry in coastal Alaska in the years to come.

As changes related to federal lands were occurring in Southeast Alaska, significant changes in the use of private forest lands of the region were also taking place. Native Alaskans had received 550,000 acres of Tongass National Forest lands as a result of the Alaska Native Claims Settlement Act (USDA Forest Service 1993b). Between 1978 and 1982, the dollar rose against the yen, making American manufactured wood prod- ucts expensive to Japanese consumers. This resulted in an expanding demand for logs exported from Native corporation lands because it became cheaper to process the logs in Japan and other Pacific Rim countries due to the relatively lower labor costs. Most of the southeast Alaska Native corporations chose to liquidate their high quality old-growth stands, and log exports increased sharply. Alaska log exports doubled between 1979 and 1983 and doubled again between 1983 and 1988 (Haynes and Brooks 1990).

From 1981 through 1991, the average annual harvest from all forest lands in Southeast Alaska averaged 709.4 million board feet. Annual harvests ranged between $520 \mathrm{mmbf}$ and 992.2 mmbf (USDA Forest Service 1993b). Because of the land classification discussed above and the fact that most of the Native corporations' old-growth lands will soon have been harvested, the annual harvest in coastal Alaska is expected to decline.

Because Alaska markets are small and transportation costs to other U.S. markets are high, nearly all Alaska's wood products are exported to foreign markets. Alaska's forest products are now shipped throughout the world, but the majority of shipments are to the markets around the Pacific Rim. Japan by far remains the single most important market for all Alaska forest products, but South Korea, Taiwan and China are important markets for softwood logs, pulp and softwood lumber. Alaska pulp is shipped to India, the Middle East and Eastern Europe (Haynes and Brooks 1990).

\section{Conclusion}

Alaskans often like to refer to their state as the "last frontier." This brief history suggests that Alaska is only a "last frontier" in a limited sense. Alaska still is a frontier because it has a relatively small population and a lot of undeveloped land. However, because this undeveloped land has mostly been spoken for, classified and planned, and because most of it is off-limits to development and cannot be appropriated, it has ceased to be a frontier. The Alaskan "frontier" is a managed frontier.

\section{References}

Arthur D. Little, Inc. 1961. Alaska's forest resources as a base for industrial development; report to the State of Alaska. Arthur D. Little, Inc., Cambridge, Massachusetts. $65 \mathrm{p}$.

Billman, E. 1975. Tlingit woodworking. Sheldon Jackson Museum, Sitka, Alaska. Tlingit Bulletin Number 4. 8 p.

Bruce, D. 1993. History of tree planting on the Aleutian Islands. In: Forest Development in Cold Climates. J. Alden et al., eds. Plenum Press, New York.

Gallagher T.J. and A.F. Gasbarro. 1989. The battles for Alaska, planning in America's last wilderness. Journal of the American Planning Association 55(4). Autumn 1989.

Harris, A.S. et al. 1974. The forest ecosystem of Southeast Alaska: 1. The setting. General Technical Report PNW-12. Portland, Oregon:USDA Pacific Northwest Forest and Range Experiment Station.

Haynes, R.W. and D.J. Brooks. 1990. An analysis of the timber situation in Alaska: 1970-2010. General Technical Report PNWGTR-264. Portland, OR: U.S. Forest Service, Pacific Northwest Research Station.

Kellogg, R.S. 1910. The forests of Alaska. U.S.D.A. Forest Service Bulletin 81. Washington DC: Government Printing Office

McGhee, R. 1989. Ancient Canada. Canadian Museum of Civilization, Hull, PQ. 174 p.

Naske, C.-M. and H.E. Slotnick. 1987. Alaska - A history of the 49th state. 2nd ed. University of Oklahoma Press, Norman, OK. 349 pp. 
Nelson, R.K. 1986. Hunters of the northern forest. The University of Chicago Press, Chicago. 303 p.

Newman, P.C. 1989. Empire of the Bay. Madison Press Books. Toronto, ON. 223 p.

Pyne, S.J. 1982. Fire in America: A cultural history of wildland and rural fire. Princeton University Press, Princeton, NJ.

Rakestraw, L.W. 1981. A history of the United States Forest Service in Alaska. Cooperative Publication of the Alaska Historical Commission, Department of Education, State of Alaska, and the Alaska Region, USDA Forest Service. Anchorage, AK. 221 p.

Trimmer, F.M. 1898. The Yukon Territory. London: Downey \& Company Limited.

University of Alaska, Institute of Business, Economic, \& Government Research. 1964. The wood products industry in Alaska. Alaska Monthly Review of Business and Economic Conditions. September, 1964. University of Alaska, Fairbanks, AK.
USDA Forest Service. 1993a. Forest resources of the United States, 1992. USDA Forest Service General Technical Report RM-234. Fort Collins, Colorado:Rocky Mountain Forest and Range Experiment Station. USDA Forest Service. 1993b. Status of the Tongass National Forest -1991. Alaska National Interest Lands Conservation Act Section 706(b), Report Number 4. Alaska Region R10 MB 238. Juneau: USDA Forest Service.

USDA Forest Service. 1994. Tongass commercial forest land; The situation past and present. Script from slide/tape program developed by USDA Forest Service, Alaska Region. Juneau, AK.

USDI, Office of Territories. 1951. Mid-century Alaska. Washington, DC: U.S. Government Printing Office. 